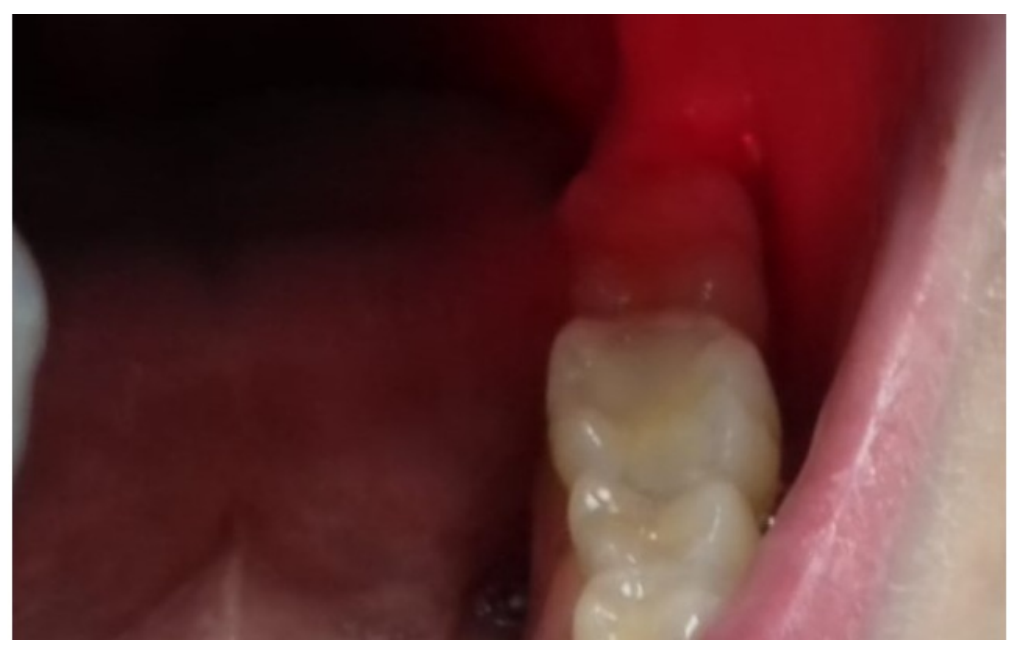

\title{
Medication-related osteonecrosis of the jaw: prevention and medical-surgical management through low-level laser therapy with different wavelengths
}

\author{
Giovanna Mosaico, Martina Salvatorina Murgia ${ }^{1}$, Cinzia Casu \\ 1 University of Cagliari \\ Funding: The author(s) received no specific funding for this work. \\ Potential competing interests: The author(s) declared that no potential competing interests exist.
}

\section{Abstract}

Medication-related osteonecrosis of the jaw (MRONJ) is on the rise among patients taking long-term antiresorptive drugs. The primary goal of treatment in osteonecrosis of the jaws (ONJ) should be to improve the patient's quality of life by managing pain and infections, preventing the development of new lesions and slowing the progression of the disease. In recent years, the use of the laser for MRONJ treatment has spread, thanks to the practical administration and the widely reported beneficial effects on tissue healing. This literature overview sought to clarify whether low-level laser therapy (LLLT) has positive effects on the treatment of osteonecrosis of the jaw. Our results show that treatment modalities, including LLLT, were associated with superior outcomes in terms of cure or improvement of antiresorptive drugs-related osteonecrosis of jaw lesions compared to conventional surgical and / or conservative drug therapy alone. It can be concluded that combined treatment with antibiotics, minimally invasive surgery (including laser surgery) and LLLT in the early stages of the disease should be the gold standard for management to MRONJ.

\section{Background:}


Medication-related osteonecrosis of the jaws (MRONJ) is defined as a drug-related adverse reaction, with the progressive destruction and necrosis of the mandibular and / or maxillary bone associated with the use of an antiresorptive agents (bisphosphonate or denosumab) and anti-angiogenetic ones, without history of radiation therapy for the craniofacial region. In fact, ONJ associated with the use of these drug classes constitutes one of the most important complications.

The main goal of treatment of ONJ should be to improve the patient's quality of life by managing pain and infections, preventing the development of new lesions and slowing the progression of the disease. In recent years, the use of laser for ONJ treatment has become more widespread, thanks to the widely reported beneficial effects on tissue healing. Currently, antibiotic therapy, minimally invasive surgery and the low level laser therapy (LLLT) during the early stages, have been considered the gold standard treatment to prevent MRONJ.

\section{Materials and Methods:}

We reviewed the literature and guidelines to try to clarify whether the LLLT has positive effects on the ONJ treatment. Scientific articles available on the main medical databases (PubMed, Cochrane, Google Scholar, Scopus) were searchedfor which inclusion and exclusion criteria were outlined (Fig. 1).

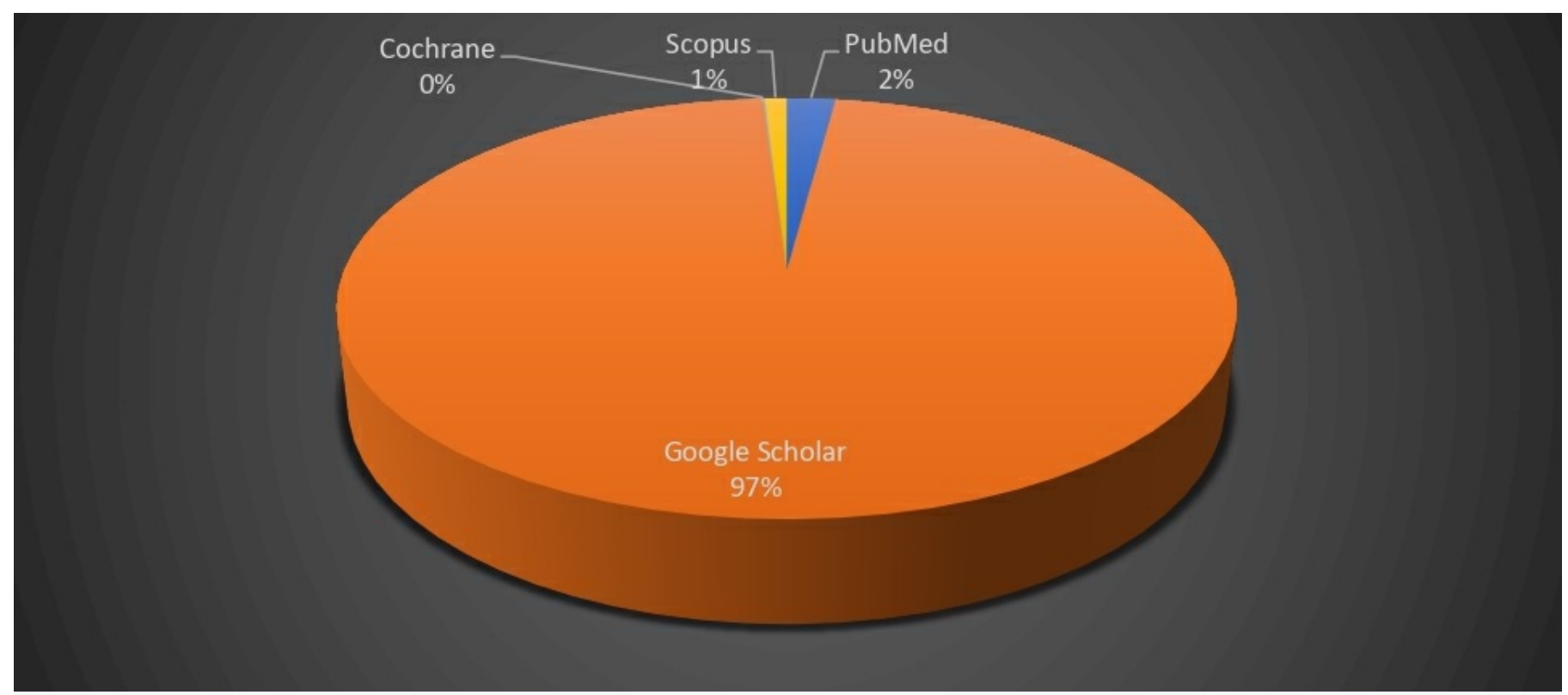

Figure 1: Qualitative and the quantitative analysis.

More specifically, the inclusion criteria were (Table 1):

- Scientific articles published without time limits;

- International articles in English;

- Expert review;

- Literature reviews;

- Meta-analysis;

- Case report;

The exclusion criteria were: 
- Scientific papers dealing exclusively with non-LLLT-associated laser surgical therapy in patients with MRONJ;

- Inability to access the full text.

\begin{tabular}{|l|l|}
\hline Inclusion criteria & Exclusion criteria \\
\hline Scientific articles published without time limits & $\begin{array}{l}\text { Scientific papers dealing exclusively with non-LLLT- } \\
\text { associated laser surgical therapy in patients with MRONJ }\end{array}$ \\
\hline International articles in English & Inability to access the full text \\
\hline Expert review & \\
\hline Literature reviews & \\
\hline Meta-analysis & \\
\hline Case report & \\
\hline
\end{tabular}

Table 1: Inclusion and exclusion criteria.

\section{Results:}

By inserting the keywords "LLLT", "Osteonecrosis of the jaws", "MRONJ", "low level laser therapy", "ONJ" 959 results were obtained. Data were extracted by two reviewers independently (GM and MMS). Any disagreement between the authors regarding the inclusion of a particular article and the extraction of the data was resolved by discussion. The PRISMA flow diagram shows the flow of information through the different phases of the review process (Figure 2).

After the exclusion of duplicates, 655 articles were evaluated, then 108 studies were left for full-text assessment. At last, 9 studies were included in the qualitative and in the quantitative analysis (Table 2). 


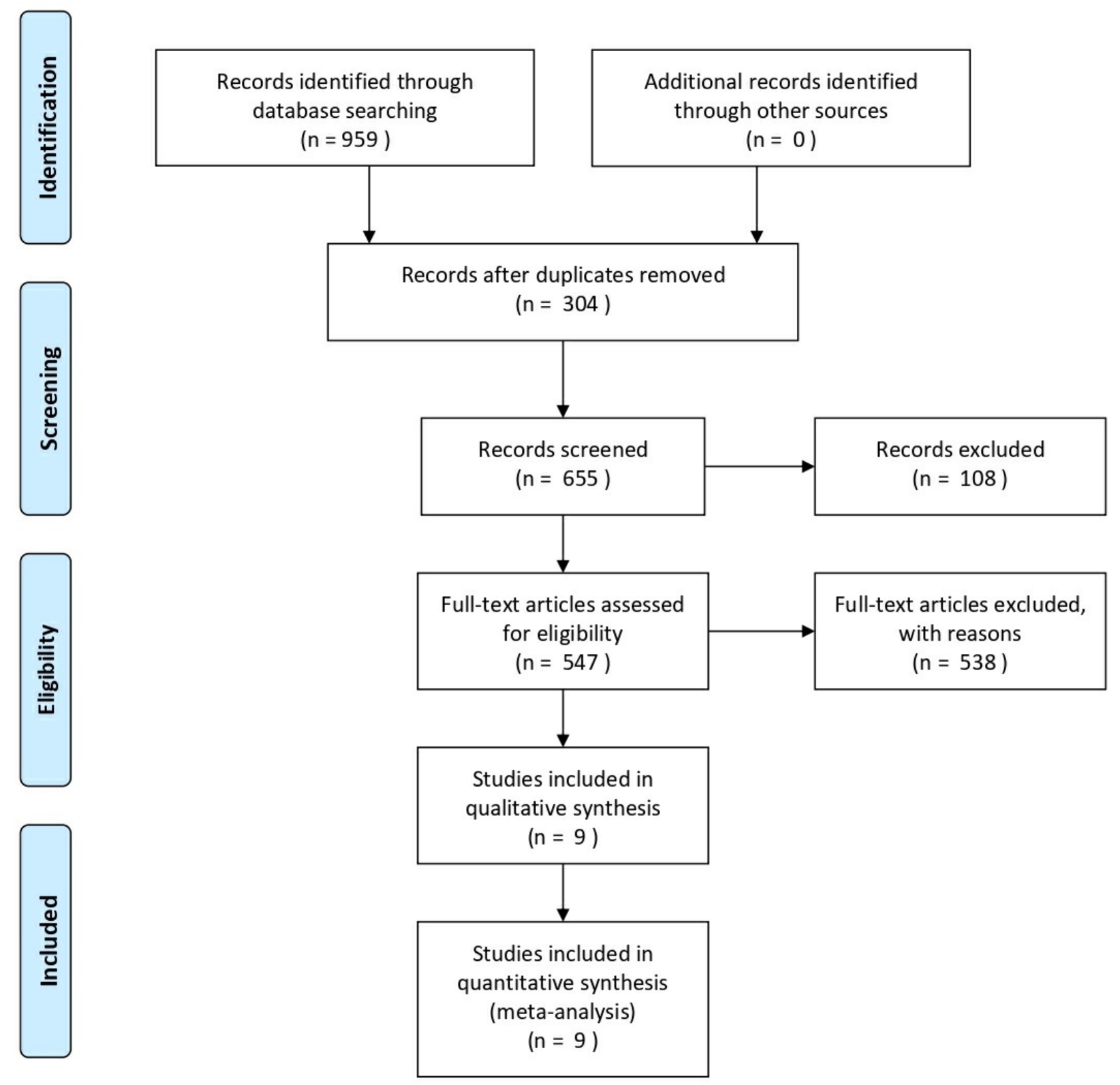

Figure 2: Flow-chart diagram for the selection of the 9 studies included in the present analysis

\begin{tabular}{|l|l|l|l|l|l|l|l|}
\hline \multicolumn{1}{|c|}{ Authors } & Type study & \multicolumn{1}{|c|}{$\begin{array}{c}\text { Laser } \\
\text { wavelength }\end{array}$} & $\begin{array}{c}\text { Power } \\
\text { laser }\end{array}$ & $\begin{array}{c}\text { Duration } \\
\text { sessions }\end{array}$ & $\begin{array}{c}\text { Duration } \\
\text { treatment }\end{array}$ & Patients & Outcomes \\
\hline $\begin{array}{l}\text { Herascu } \text { et al. } \\
2005\end{array}$ & Case report & $\begin{array}{l}\text { Diode, } 904 \\
\pm 2 \mathrm{~nm}\end{array}$ & $5 \mathrm{~W}$ & 6 minutes & 6 days & 1 & Complete healing \\
\hline Chow et al. & Research & Diode, 830 & $1 \mathrm{~W}$ & 2 minutes & 1 day & In vitro & Photoacceptors in
\end{tabular}




\begin{tabular}{|c|c|c|c|c|c|c|c|}
\hline 2007 & report & $\mathrm{nm}$ & & & & study & $\begin{array}{l}\text { the mitochondrial } \\
\text { membrane absorb } \\
\text { laser and mediate } \\
\text { the transduction of } \\
\text { laser energy into } \\
\text { electrochemical } \\
\text { changes, initiating } \\
\text { a secondary } \\
\text { cascade of } \\
\text { intracellular events }\end{array}$ \\
\hline $\begin{array}{l}\text { Vescovi et al. } \\
2013\end{array}$ & Case series & $\begin{array}{l}\text { Nd:YAG } \\
\text { laser } 1064 \\
\mathrm{~nm}\end{array}$ & $1,25 \mathrm{~W}$ & 5 minutes & $\begin{array}{l}3 \text { days and } \\
\text { once a } \\
\text { week for } 2 \\
\text { months }\end{array}$ & 217 & Complete healing \\
\hline $\begin{array}{l}\text { Caroll et al. } \\
2014\end{array}$ & Review & $\begin{array}{l}\text { LED } \\
\text { devices, } \\
600-1000 \\
\mathrm{~nm}\end{array}$ & $1-10 \mathrm{~W}$ & $\begin{array}{l}30-60 \\
\text { seconds }\end{array}$ & $\begin{array}{l}\text { Not } \\
\text { specified }\end{array}$ & $\begin{array}{l}\text { Not } \\
\text { specified }\end{array}$ & $\begin{array}{l}\text { Efficacy at many } \\
\text { sites within the } \\
\text { body and for } \\
\text { treatment of a } \\
\text { range of } \\
\text { musculoskeletal } \\
\text { injuries, } \\
\text { degenerative } \\
\text { diseases and } \\
\text { dysfunction }\end{array}$ \\
\hline $\begin{array}{l}\text { Altay et al. } \\
2016\end{array}$ & Case series & $\begin{array}{l}\text { Diode, } 808 \\
\mathrm{~nm}\end{array}$ & $0,5 \mathrm{~W}$ & 2 minutes & $\begin{array}{l}1,3,5,7 \\
\text { and } 10 \text { days } \\
\text { after } \\
\text { extractions }\end{array}$ & 11 & $\begin{array}{l}\text { Favourable results } \\
\text { and healing in all } \\
\text { patients }\end{array}$ \\
\hline $\begin{array}{l}\text { Latifyan et al. } \\
2016\end{array}$ & Review & $\begin{array}{l}\text { LED } \\
\text { devices, } \\
650-1064 \\
\mathrm{~nm}\end{array}$ & $\begin{array}{l}\text { Not } \\
\text { specified }\end{array}$ & $\begin{array}{l}\text { Not } \\
\text { specified }\end{array}$ & $\begin{array}{l}\text { Not } \\
\text { specified }\end{array}$ & $\begin{array}{l}\text { Not } \\
\text { specified }\end{array}$ & $\begin{array}{l}\text { Control pain, as } \\
\text { well as } \\
\text { biostimulating } \\
\text { properties with } \\
\text { favourable actions } \\
\text { on bacterial } \\
\text { control and wound } \\
\text { healing }\end{array}$ \\
\hline $\begin{array}{l}\text { Weber et al. } \\
2016\end{array}$ & Review & \begin{tabular}{|l|} 
LED \\
devices, \\
$660-2940$ \\
$\mathrm{~nm}$ \\
\end{tabular} & $\begin{array}{l}\text { Not } \\
\text { specified }\end{array}$ & $\begin{array}{l}\text { Not } \\
\text { specified }\end{array}$ & $\begin{array}{l}\text { Not } \\
\text { specified }\end{array}$ & $\begin{array}{l}\text { Not } \\
\text { specified }\end{array}$ & $\begin{array}{l}\text { LLLT should be } \\
\text { the gold standard } \\
\text { for ONJ } \\
\text { management }\end{array}$ \\
\hline $\begin{array}{l}\text { Minamisako et } \\
\text { al. } 2016\end{array}$ & $\begin{array}{l}\text { Case } \\
\text { Report }\end{array}$ & $\begin{array}{l}\text { Diode, } 808 \\
\mathrm{~nm}\end{array}$ & $0,1 \mathrm{~W}$ & 3 minutes & $\begin{array}{l}\text { twice a } \\
\text { month } \\
\text { during } 6 \\
\text { months } \\
\text { after wound } \\
\text { healing }\end{array}$ & 1 & $\begin{array}{l}\text { Healing and } \\
\text { improvement of } \\
\text { patient's quality of } \\
\text { life }\end{array}$ \\
\hline $\begin{array}{l}\text { Momesso et al. } \\
2017\end{array}$ & $\begin{array}{l}\text { Case } \\
\text { Report }\end{array}$ & $\begin{array}{l}\text { Diode, } 810 \\
\mathrm{~nm}\end{array}$ & 0,1 & 35 seconds & 8 weeks & 1 & $\begin{array}{l}\text { Good bone healing } \\
\text { in evolution }\end{array}$ \\
\hline
\end{tabular}

Table 2: Included articles.

MRONJ treatment strategies recommended should be oral antibiotic therapy, chlorhexidine gluconate $0.12 \%$ mouth rinses, conservative debridement of bone sequestrum and infection control. Beside these approaches, LLLT was applied as adjuvant treatment. 
The application of LLLT has been successfully reported as an adjuvant treatment in the management of both surgical and non-surgical MRONJ.

LLLT can provide significant improvement in signs of inflammation (mainly swelling and pain), xerostomia, bacterial control and chemotherapy-induced oral mucositis. Therefore, it's effective in patients with MRONJ, preventing oral or cutaneous fistulas and healing the mucosa on the bone tissue and improving the patient's quality of life.

In addition, LLLT prevents evolution di ONJ from stage 2 (exposed and necrotic bone or a fistula with evidence of infection, typically asymptomatic and symptomatic) to stage 3 (exposed and necrotic bone or fistulas with evidence of infection and with pathological fracture or exposed necrotic bone, extraoral or oral antral or oral-nasal communication, osteolysis extending to the lower edge of the mandible or sinus floor). The biostimulating effect of numerous wavelengths improves reparative processes, increases the inorganic bone matrix and the mitotic index of osteoblasts as well stimulates the growth of blood and lymphatic. The literature shows evidence that the use of LLLT has proven to be a promising adjuvant treatment for the management of MRONJ due to its ability to modulate cellular metabolism, improve wound healingand relieve pain.

The biostimulating effect of laser irradiation expands the organic bone matrix and increases the mitotic index of osteoblasts, stimulating its proliferation and differentiation and increasing the number of differentiated osteoblastic cells and their activity. Furthermore, LLLT is a non-invasive method with antibacterial and biostimulating effects on soft and hard tissues. In addition, it has also proangiogenic factors.

Several authors have evaluated the biostimulatory effects of LLLT performed across different wavelengths on the of bones and mucous membranes trophism, both in vitro and in vivo. The phenomena reported include faster wound healing, increased proliferation of fibroblasts and chondroblasts, collagen synthesis, stimulation of osteogenesis, bone cell differentiation and bone repair mechanisms, increased blood flow, stimulation of endothelial cell proliferation and analgesia. Fistula remission, absence of bone necrosis, control of infection and / or suppuration, pain relief and total oral mucosal repair were observed through these adjuvant therapies.

Vescoviet al. tested the hypothesis that the combination of antibiotic therapy and LLLT could be effective in preventing MRONJ after tooth extraction in patients on bisphosphonate therapy. Altay et al. stated that the use of LLLT not only promotes biostimulating properties, analgesia and wound healing, but also optimizes clinical evolution and treatment time compared to conventional management. Finally, Latifyanet al. also pointed out that this adjuvant treatment is not associated with any known side effects.

\section{Conclusions.}

Biostimulation could represent an adjunct therapy in the treatment of the "initial" forms of drug-related ONJ, in patients with both oncological and osteometabolic pathology, as a safe, minimally invasive and well tolerated technique.

\section{[1][2][3][4][5][6][7][8][9]}

\section{References}


1. 'Gustavo Antonio Correa Momesso, Fábio Roberto de Souza Batista, Cecília Alves de Sousa, Valthierre Nunes de Lima, et al. (2017). Successful Use of Lower-Level Laser Therapy in the Treatment of Medication-Related Osteonecrosis of the Jaw. J Lasers Med Sci, vol. 8 (4), 201-203. doi:10.15171/jlms.2017.37.

2. 'Mariana Comparotto Minamisako, Guilherme Henrique Ribeiro, Mariáh Luz Lisboa, Mabel Mariela Rodríguez Cordeiro, et al. (2016). Medication-Related Osteonecrosis of Jaws: A Low-Level Laser Therapy and Antimicrobial Photodynamic Therapy Case Approach. Case Reports in Dentistry, vol. 2016, 1-4. doi:10.1155/2016/6267406.

3. ^3. J. D. Carroll, M. R. Milward, P. R. Cooper, M. Hadis, and W. M. Palin. (2014.). , "Developments in lowlevel light therapy (LLLT) for dentistry,". DentalMaterials,, vol. vol. 30, no. 5, pp. 465-475, .

4. ^4. R. T. Chow, M. A. David, and P. J. Armati. (2007). $830 \mathrm{~nm}$ laser irradiationinducesvaricosityformation, reducesmitochondrial membrane potential and blocks fast axonal flow in small and medium diameterratdorsalrootganglionneurons: implications for the analgesiceffects of $830 \mathrm{~nm}$ laser. ," Journal of the PeripheralNervous System,, vol. vol. 12, no. 1, pp. 28-39, .

5. ^ 5. N. Herascu, B. Velciu, M. Calin, D. Savastru, and C. Talianu. (2005.). Low-level laser therapy (LLLT) efficacy in post-operative wounds,. Photomedicine and Laser Surgery,, vol. vol. 23, no. 1, pp. 70-73, .

6. ^ 6. P. Vescovi, M. Meleti, E. Merigo et al.,. (2013.). Case series of 589 toothextractions in patients under bisphosphonatestherapy. Proposal of a clinicalprotocolsupported by Nd:YAGlow-level laser therapy,". Medicina Oral, PatologíaOral y CirugíaBucal,, vol. vol. 18, no. 4, pp. e680-e685,

7. ^7. M. A. Altay, F. Tasar, E. Tosun, and B. Kan,. (2016.). Low-level laser therapysupportedsurgical treatment of biphosphonaterelatedosteonecrosis of jaws: a retrospectiveanalysis of 11 cases,". Photomedicine and Laser Surgery,, vol. vol. 34, no. 6, pp. 263-271, .

8. ^8. S. Latifyan, M. T. Genot, and J. Klastersky,. (2016.). Bisphosphonate-relatedosteonecrosis of the jaw: a review of the potentialefficacy of low-level laser therapy,". Supportive Care in Cancer,, vol. vol. 24, no. 9, pp. 3687-3693, .

9. ^9. Weber JB, Camilotti RS, Ponte ME.. (2016). Efficacy of laser therapy in the management of bisphosphonaterelatedosteonecrosis of the jaw (BRONJ): a systematicreview. LasersMed Sci., vol. 1261-72 . 